\title{
Variation in Adaptive Traits of an Endemic Meconopsis napaulensis DC. along an Elevation Gradient in Alpine Himalaya, Central Nepal
}

\author{
Narmada Rana, Suresh Kumar Ghimire \\ Tribhuvan University, Kathmandu, Nepal \\ *Corresponding Author: Narmada Rana: narmadarana123@gmail.com
}

\section{OPEN ACCESS}

Citation: Rana N., Ghimire S. K. (2016)Variation in Adaptive Traits of an Endemic Meconopsis napaulensis DC. along an Elevation Gradient in Alpine Himalaya, Central Nepal.Open Science Journal 2(1).

Received: $4^{\text {th }}$ Juy 2016

Accepted: $17^{\text {th }}$ November 2016

Published: $6^{\text {th }}$ February 2017

Copyright:@ 2016 This is an open access article under the terms of the Creative Commons

Attribution License, which permits unrestricted use, distribution, and reproduction in any medium, provided the original author and source are credited.

Funding: The author(s) received no specific funding for this work.

Competing Interests: The author have declared that no competing interests exists.

\section{Abstract}

Understanding the pattern of variation in adaptive traits of rare and endemic species along environmental gradient can suggest important implications for developing optimal strategies for species conservation and sustainable management. In this study we aimed to study variation in life-history traits of an endemic species $M$. napaulensis DC. along an elevation gradient in Langtang National Park, Central Nepal covering three populations. Each population was investigated two times (2013 and 2014) covering different seasons. Population sampling was made to read habitat during the peak growing period (during monsoon) except seed output, which was studied during the late growing period (post monsoon). Entire area of each population was extensively surveyed to record all the individuals, including plants in flowering or fruiting and their detailed vegetative characteristics and traits related to population fitness. Analysis of the habitat features showed that M. napaulensis exhibited high habitat specificity. M. napaulensis was restricted to open and rocky habitats of high altitudes. $M$. napaulensis growing sites had low vegetation cover indicating decreased interspecific competition. M. napaulensis showed high variation in traits due to altitudinal variation, climatic conditions, and disturbances. 
Specifically, reproductive traits discriminated the populations. $M$. napaulensis was suffered from human disturbance mainly from livestock grazing, plant harvesting, and garbage pollution as the study area is an important tourist destination and pilgrimage site. Conservation of rare and endemic species such as M. napaulensis requires strong provisions restricting human activities and minimizing the impact of harvesting and grazing; and implementing habitat restoration and population augmentation programs.

Keywords: Endemic, Elevation gradient, Population ecology, Density, Vegetative traits, Reproductive traits.

\section{Introduction}

Elevation gradient is correlated with several environmental factors. With the increasing elevation, plant populations are subjected to a gradually decreasing mean temperature, and a shorter growing season (Landolt, 1967; Körner, 2003). Elevation gradient is therefore ideally suited for examining variations in species' traits, which strongly influence fitness (Minden, 2010), including growth and competition (Wright et al., 2006). Plant adaptive traits are evolved in response to the changing environmental conditions, and therefore exhibit considerable variations along elevation gradients (Westoby and Wright, 2006), including gradients associated with disturbance (Daiz et al., 1999; Wana and Beierkuhnlein, 2009). When comparing plant populations growing on lower elevation areas with that of higher elevation, an obvious adaptation of high altitude plants to the adverse environment is found to be in the reduced size (Jenny-Lips, 1948; Körner, 2003). Plant species growing along the elevation gradient show considerable variations in life history strategies, including the structure of their populations and demography (Kim and Donohue, 2011). Studies pertaining to variations in adaptive traits along the elevation gradient may provide opportunities to examine performances of plant populations under environmental changes (Kim and Donohue, 2011).

In a high altitude ecosystem, plant populations are subjected to an increasing level of anthropogenic pressure, created by habitat destruction, deforestation, and overexploitation (Ghimire et al., 2008; Sharma et al., 2009). Such areas are particularly vulnerable to natural variations in climate (Sano et al., 2005; Cavaliere, 2009; Salick et al., 2009). Studies have shown that populations of rare endemic species exhibit reduced size, altered population structure, reduced fitness, and ultimately face greater extinction risk in the response to altered environmental conditions at high altitudes (Brune and Kress, 2002; Lavergne, 2005; Colling and Matthies, 2006; Dar et al., 2006). Reduced fitness in many rare and endemic species is associated with limited success in sexual reproduction, which can be attributed to reduced pollination, failure in the formation of viable 
seeds, increased herbivory and predation pressure (Morely, 1982; Menges et al., 1986; Karran, 1987; Lavergne, 2005; Albert et al., 2005).

Seed size is the prominent life history trait that affects seed dispersal, seedling establishment and survival (Leishman et al., 2000). Under the increasingly adverse ecological conditions along an altitudinal gradient, seedlings from heavy seeds might be more successful in establishment and survival (Leishman et al., 2000; Moles and Westoby, 2004). Studies have shown that alpine plant species exhibit a reduction in seed size with the increasing elevation. Low temperatures and short growing seasons at high elevations are the two most important factors affecting seed maturation and seed weight (Totland and Birks, 1996; Totland 1997a; Wagner and Reichegger, 1997; Baskin and Baskin 1998; Blionis and Vokou, 2005).

In alpine environments, plant demography is often characterized by low seedling recruitment and high mortality at early developmental stages compared with lower-elevation populations (Billings and Mooney, 1968). Demographic rates in plants are usually stage-dependent (Harper, 1977), the structure of a population may be indicative for its demographic future. Moreover, lowered seed output is one of the major threats to plant life-history processes influencing the population age-stage structure directly, and may increase the probability of extinction of populations and species in the long-run (Lennartsson, 2002).

Long-term persistence of a species population depends on the continuous regeneration (Thakuri, 2010). A regeneration of a species is greatly influenced by habitat conditions. However, a natural regeneration of a species largely depends on production and germination of seeds and the establishment and survival of seedlings. Potentialities of a species' regeneration can be depicted through the analysis of population structure (i.e. the proportion of plant individuals classified into different stage/age classes) (Bharali et al., 2012). Study on the variation in population structure along elevation gradients would be helpful in understanding the influences of environmental factors on regeneration (Wang et al., 2004).

The present study was conducted to assess the responses of Meconopsis napaulensis populations along the elevation gradient in north-central Nepal. Meconopsis napaulensis is an endemic species, distribution of which is restricted to the alpine areas of Langtang National Park, north-central Nepal. The conservation and management of rare and endemic species is a major challenge in the Himalaya. The genus Meconopsis as whole is one of the critically threatened taxa (Sulaiman and Babu, 1996). Among the species in Meconopsis, rare and endemic ones, such as M. napaulensis, are predicted to be more vulnerable. This study explores habitat properties, population structure, and fitness-related traits of $M$. napaulensis along the elevation gradient, which can provide a link between population responses to the environmental change.

\section{Methods}

\section{Study area}

The study was undertaken in upper Trishuli valley between Lauribina danda to Gosainkunda in north-central part of Langtang National Park (LNP). Langtang National Park (LNP) was established in 1976 to conserve the unique 
flora and fauna of the region. LNP covers an area $1,710 \mathrm{sq}$. $\mathrm{km}$. It is located at $28^{\circ} 28^{\prime} 20^{\prime \prime} \mathrm{N}$ latitude and $85^{\circ} 15^{\prime} 86^{\prime \prime}$ E longitude. Elevation in the park ranges from 792 to $7245 \mathrm{~m}$. The area is rich in terms of flora and vegetation. The focused study area covers alpine zone with an elevation range of 4000-4500 m a.s.l. Meconopsis species are the important component of vegetation on the alpine zone in upper Trishuli valley.

\section{Distribution}

The genus of Meconopsis Vig. (Family: Papaveraceae) consists of 55 species distributed in the Himalaya (Egan and Shrestha, 2011). In total, 22 species are reported from Nepal, out of which 11 are endemic to the high altitude areas between 2400-4900 m (Grey-Wilson, 2006). Most of the endemic species of Meconopsis are restricted to Central Nepal; there are only three endemic species in Western Nepal (i.e., M. chankheliensis, M. simikotensis and M. regia) and one (M. dhwojii) in Eastern Nepal (Egan and Shrestha, 2011) (Appendix I). The endemic $M$. napaulensis is very local in distribution and is known only from Gosainkunda and Ganesh Himal area of Langtang National Park, and its adjoining region in Rasuwa district, central Nepal (Grey-Wilson, 2006). It is found in rocky, grassy slopes, open shrub berries, open rocky shrubs, rocky grassland, and stream- margins at 3200-4500 m a.s.l. (Egan and Shrestha, 2011).

\section{Ecology}

The members of the genus Meconopsis are poorly known with respect to their reproduction traits, fitness, and population ecology. Sulaiman and Babu (1996) found that Meconopsis species are habitat specialist. In Meconopsis, a large number of seeds are produced but most of them are exposed to a high level of insects, fungal and viral infections (Sulaiman and Babu, 1996). Germination and seedling recruitment have also been reported to be very low both in natural habitat and under laboratory conditions (Xie et al., 2002). Several studies conducted for different species of genus Meconopsis revealed the existence of physiological dormancy hindering seed germination (Sulaiman 1993; Dar et al., 2009).

\section{Sampling}

The study was completed in two field visits (the first visit was made in 2013 and the second visit in 2014). The distribution of $M$. napaulensis populations in the study area was recorded with the help of GPS device and consultations with local people. Based on the information obtained from the field survey, as well as from literature and herbarium study, the whole of the distribution range of $M$. napaulensis was divided into three distinct elevation levels each representing distinct population: (i) lower elevation (4117-4125 m) in Lauribina danda, (ii) mid-elevation (4200-4255 m) in Lauribina pass, and (iii) higher elevation (4396$4417 \mathrm{~m}$ ) in Gosainkunda.

In each elevation level, M. napaulensis was sampled in four plots of $10 \times 10$ $\mathrm{m}$ size. The plots were laid systematically in the area where $M$. napaulensis density was high. Each plot was divided into 4 subplots $(5 \times 5 \mathrm{~m})$; and thus altogether 48 such subplots were sampled from all the three elevation levels. Most 
of the population parameters were collected during the peak growing period in July (during monsoon) except seed output, which was studied during the late growing period in September (post monsoon season).

\section{Data Collection}

In each subplot, presence/absence of plant species associated with $M$. napaulensis was recorded. In boththe years (2013 and 2014), sampling consisted of recording all the individuals of $M$. napaulensis, classified into four different life cycle stages, on the basis of the plant size, reproductive stage and the number and size (length) of the largest leaf; small rosette (leaf number 1-7; largest leaf length 1-6 cm), juvenile rosette (leaf number 3-28; largest leaf length 6-14 cm), large rosette (leaf number 4-45; largest leaf length $>14 \mathrm{~cm}$ ), and reproductive adult (with flowering/fruiting peduncle). Each of these individuals was tagged by aluminium tag in 2013 and was monitored for the change in the population structure in 2014.

Longitude, latitude, and elevation were recorded for each sampling plot with the help of global positioning system device (GPS, eTrex Garmin). Elevation data was cross-checked with an altimeter. Slope and aspect were recorded by a clinometer-compass. Habitat parameters for each subplot further included soil $\mathrm{pH}$, soil moisture, litter depth, vegetation composition, and ground surface cover by vegetation or physical components of the environment. Soil moisture and $\mathrm{pH}$ were recorded by using a gauge (soil pH and moisture tester; model DM 15) with a default scale of 1 to 8 for moisture and 1 to 7 for $\mathrm{pH}$ recording. Similarly, soil depth was measured by inserting an iron peg. In each subplot, $\mathrm{pH}$, moisture, and depth were measured diagonally at three different points.

The anthropogenic disturbance was recorded in each plot. The disturbance variables included harvesting, garbage pollution, and grazing. As Gosainkunda is known for its pilgrimage, more pilgrims visit every year in August especially in 'Janaipurnima'. They pluck flowers for offering to God and also pluck roots, fruits, and seeds for medicinal purposes (based on interviews with local people) so there is a high rate of harvesting. In addition, garbage pollution was recorded along the trekking route due to more flow of people for trekking which turned more use of things along the trekking route (based on interviews with local people). The harvesting impact was recorded by direct observation of plant uprooting or by observing the scars left after plucking of flowers and/or fruits. Each type of disturbance was scored by categorical scale as no disturbance, moderate disturbance, high disturbance, very high disturbance.

\section{Vegetative and reproductive attributes}

All the individuals from each subplot were marked in 2013 by aluminium tag. Each individual was thoroughly inspected for recording a number of vegetative and reproductive traits having significant adaptive value to the plant. Parameters recorded from the individuals in rosette stage (non-reproductive) were the total number of leaves, and the length of the largest leaf. Parameters recorded from the individuals in reproductive adult stage included plant height, and the number of buds, flowers, and fruits (capsules). 
The number of flowers and buds were counted in the flowering period and the number of capsules in the fruiting period. During the flowering period, 5 flowering individuals from each population were randomly selected and their flowers $(n=2)$ were collected for the study of pollen viability. Similarly, during the fruiting period, 5 matured individuals were marked per population for capsule harvesting. From each such plant, at least five matured but unopened capsules were collected. Ten such capsules were randomly selected per population for the measurement of seed size (in terms of seed mass) and seed viability. Capsule size was measured with the help of Vernier calliper. Both length and diameter of a capsule were measured. The diameter was recorded as the mean of upper, middle and lower portions of the capsule.

\section{Pollen and seed viability}

Glycero acetocermine (1:1) mixture was used for the treatment of pollen viability test assessed by Belling's Iron-Aceto-Carmine staining method (Singhal and Kumar, 2008). Pollen grains from each flower were treated with Glycero acetocermine (1:1) mixture and were studied under a compound microscope. Well-filled pollen grains with stained nuclei were regarded as fertile/viable, while shriveled and unstained pollen were counted as sterile. Similarly, for the seed viability, Triphenyl tetrazolium chloride (TTC) test (Baskin and Baskin, 1998; Lin et al., 2001) was used. In this process, seeds of M. napaulensis, collected from different populations, were cut into two equal halves in such a way that each part got a portion of the embryo. Then treated with 1\% solution of TTC (Dar et al., 2009) and observed under stereo-microscope. Seed viability was revealed by pink TTC precipitation produced by dissected seeds. Embryos that turned pink were considered as viable and other as non-viable.

\section{Data Analysis}

Habitat characteristics of $M$. napaulensis were evaluated by non-parametric Kruskal- Wallis one-way analysis of variance (ANOVA) as the data was found not normal. Variables related to the anthropogenic impact were combined by using Principle Component Analysis (PCA) to obtain an overall measure of disturbance. In this process, the impact of harvesting and garbage pollution was combined as an overall measure of the human impact and was obtained explaining $63.49 \%$ variance and grazing as a measure of the livestock impact.

The numbers of associated species present per subplot were combined to calculate abundance in an ordinal scale from 0 to 4 , where 0 represents absence in all subplots and 4 presence in all subplots. The abundance data of 71 associate species from all 48 subplots were used to calculate their frequency and dominance mean value in lower, middle, and higher elevation sites.

Variations in population density and structure were studied at subplot level $\left(\begin{array}{llll}5 & \mathrm{x} & 5 \mathrm{~m}\end{array}\right)$. Population structure indicated the proportions of individuals of different life cycle stage (small rosette, juvenile rosette, large rosette, and adults). Variation in population density among elevation sites was compared using Kruskal-Wallis test. 
Vegetative and reproductive traits were computed for each adult individual in the respective elevation site. The total data set comprised of 75 adult individuals. The sample size for estimating capsule production comprised of 69 individuals of which 25 individuals from each, the lower and the middle site, and 19 individuals from the higher site, each individual's seed weight was recorded. Similarly, the sample size for viability test for seed and pollen comprised of 30 individuals of which 10 individuals from each, the lower elevation to the higher elevation.

Kruskal-Wallis test and independent sample Wilcoxon test were used to assess the variation in vegetative and reproductive traits, including seed and pollen viability, among and between study sites (Table 1). SPSS version 16.0 was used for all statistical analysis. Arc GIS 9.3 version was used for mapping.

\section{Results}

The habitats of M. napaulensis differed significantly in 6 out of 15 variables studied. Coverage of herbs was greater at the higher elevation site and that of shrubs was higher at the lower elevation site. The litter coverage was found significantly higher at the lower elevation which showed that habitat at the lower site was more fertile than at the upper site. Among the edaphic variables, the value of soil depth was high at the lower site. As the elevation increases, more rock and scree are found due to which the amount of soil and its depth reduced at the high altitude. The level of human disturbance was high in plots on the higher elevation sites. In general, higher proportions of sub-plots in populations at Gosainkunda and Lauribina pass received higher levels of garbage pollution and high livestock grazing pressure (Figure 1).

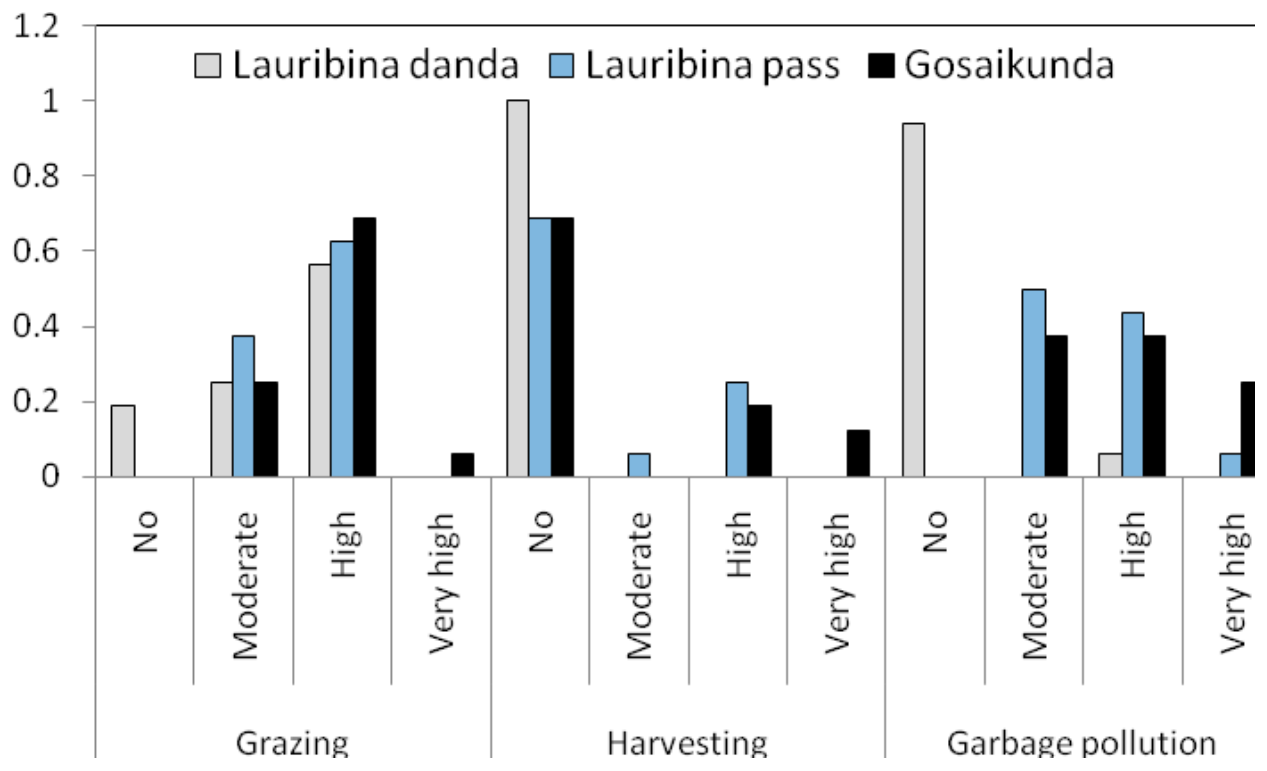

Figure 1. The level of disturbances in the three study sites. Bars represent proportion of sub-plots receiving different levels of disturbance. 


\section{Population density}

The densities of small rosette (SR), juvenile rosette (JR), large rosette (LR), and adult of $M$. napaulensis in the entire study site were found to be $0.072 \pm 0.016, \quad 0.124 \pm 0.029, \quad 0.194 \pm 0.027, \quad$ and $0.080 \pm 0.018$ (mean \pm SE) individuals per $25 \mathrm{~m} 2$ (Figure 2). The overall density combining all four stage classes was $0.470 \pm 0.061$ individuals per $25 \mathrm{~m} 2$. The value of total plant density tended to be high at the higher elevation site, but the result was statistically insignificant.

\section{Population structure}
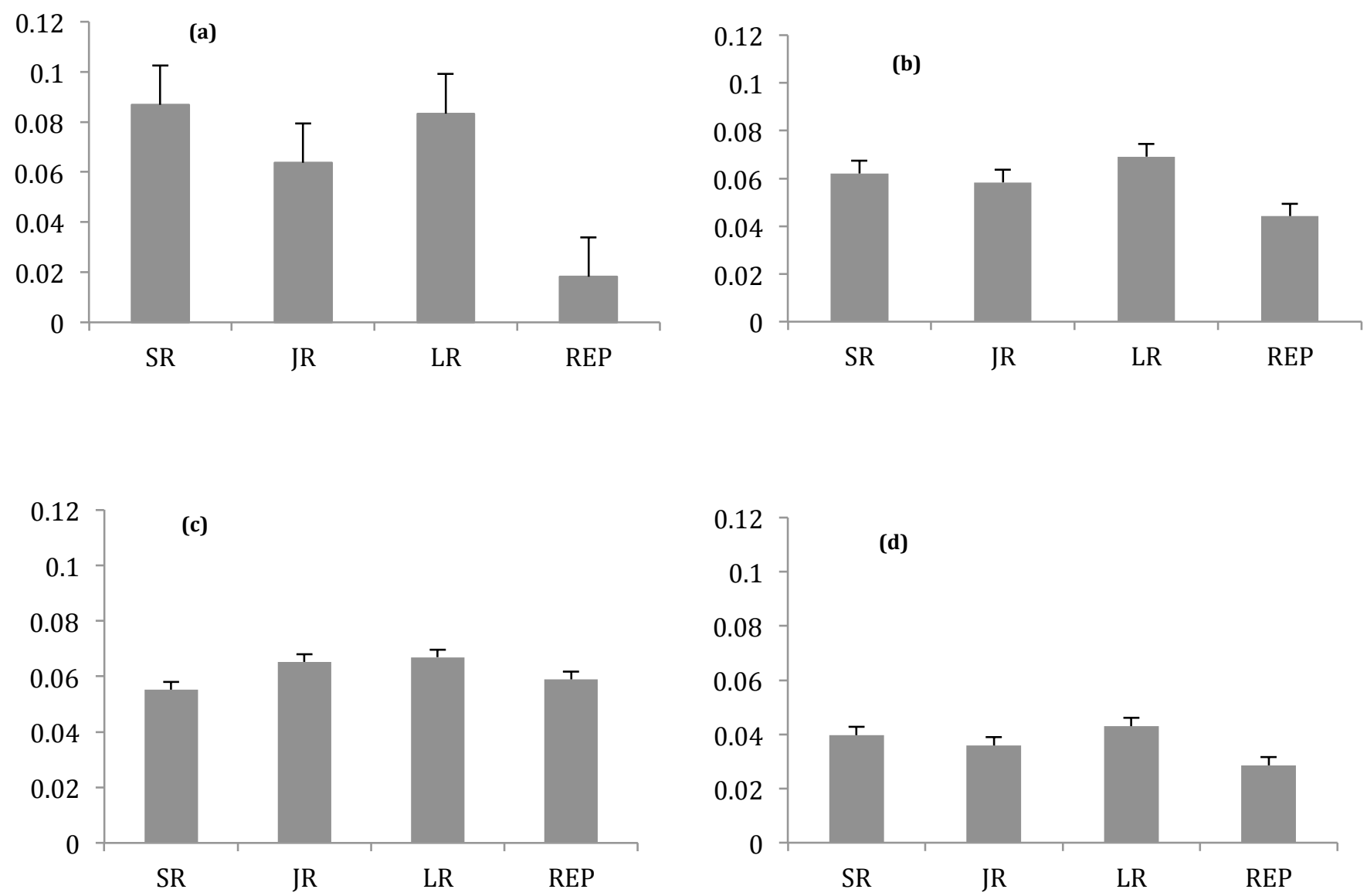

Figure 2. Population Structure. Proportion (mean $=\mathrm{SE}$ ) of small rosette (SR), juvenile rosette(JR), large rosette(LR) and adult(REP) and overall pattern of M. nepaulensis at three elevation sites in Upper Trishuli Valley of Langtang (a-c):(a) Lauribina danda (4117-4125m); (b) Lauribina pass (4200-4255m), (c) Gosainkunda(4396-4417m) and (d) Overall Population Structure. 
Table 1. Variation in vegetative and reproductive traits, including seed and pollen viability

\begin{tabular}{|c|c|c|c|c|c|c|c|c|c|c|}
\hline \multirow{2}{*}{$\begin{array}{l}\text { Variables } \\
\text { (LD) }\end{array}$} & \multirow[t]{2}{*}{$\mathbf{N}$} & \multicolumn{3}{|c|}{ Mean $\pm \mathrm{SE}$ at three sites } & \multirow[t]{2}{*}{$\begin{array}{l}\text { Overall } \\
\text { Mean } \pm \mathrm{SE}\end{array}$} & \multicolumn{2}{|c|}{$\begin{array}{l}\text { Kruskal-Wallis test } \\
\text { among sites* }\end{array}$} & \multicolumn{3}{|c|}{$\begin{array}{l}\text { Z-values indicating difference } \\
\text { between } ¥\end{array}$} \\
\hline & & & $(\mathbf{L P})$ & $(\mathrm{GK})$ & & $\chi^{2}$ & $p$-value & $\mathrm{LD} \& \mathrm{LP}$ & LD \& GK & LP \& GK \\
\hline Plant height $(\mathrm{cm})$ & 75 & $78.00 \pm 1.53$ & $74.2 \pm 2.26$ & $66.00 \pm 3.71$ & $73.32 \pm 1.52$ & 6.547 & $0.038^{*}$ & $-1.968^{*}$ & $-2.498^{*}$ & -0.06 \\
\hline No. of buds per plant & 189 & $17.2 \pm 1.8$ & $13.4 \pm 1.83$ & $8.05 \pm 1.01$ & $13.30 \pm 1.05$ & 15.166 & $0.001^{* *}$ & -1.716 & $-3.877^{* * *}$ & $-2.305^{*}$ \\
\hline No .of flowers per plant & 101 & $8.4 \pm 0.7$ & $8.00 \pm 0.86$ & $4.63 \pm 0.72$ & $7.22 \pm 0.48$ & 9.527 & $0.009^{* *}$ & -0.489 & $-2.993^{* *}$ & $-2.394^{*}$ \\
\hline $\begin{array}{l}\text { No. of capsules per } \\
\text { plant }\end{array}$ & 69 & $24.2 \pm 2.38$ & $19.6 \pm 2.47$ & $9.95 \pm 1.66$ & $18.61 \pm 1.48$ & 17.359 & $<0.001 * * *$ & -1.716 & $-3.871^{* * *}$ & $-2.991^{* * *}$ \\
\hline Capsule length $(\mathrm{cm})$ & 69 & $3.91 \pm 0.12$ & $3.8 \pm 0.00$ & $3.00 \pm 0.00$ & $3.62 \pm 0.06$ & 36.337 & $<0.001 * * *$ & -1.57 & $-4.732^{* * *}$ & $-6.557^{* * *}$ \\
\hline Capsule diameter $(\mathrm{cm})$ & 69 & $0.46 \pm 0.01$ & $0.47 \pm 0.01$ & $0.48 \pm 0.01$ & $0.47 \pm 0.01$ & 1.946 & 0.378 & -0.679 & -1.28 & -0.948 \\
\hline $\begin{array}{l}\text { Capsule mass in } \mathrm{g} \\
\text { (with seeds) }\end{array}$ & 69 & $0.16 \pm 0.01$ & $0.15 \pm 0.01$ & $0.14 \pm 0.02$ & $0.15 \pm 0.01$ & 3.59 & 0.166 & -0.466 & $-1.885^{*}$ & -1.339 \\
\hline $\begin{array}{l}\text { Capsule mass in } \mathrm{g} \\
\text { (without seeds) }\end{array}$ & 69 & $0.08 \pm 0.01$ & $0.09 \pm 0.01$ & $0.1 \pm 0.01$ & $0.09 \pm 0.01$ & 2.176 & 0.337 & -0.398 & -1.328 & -1.211 \\
\hline Seed mass/capsule in $\mathrm{g}$ & 69 & $0.08 \pm 0.01$ & $0.07 \pm 0.01$ & $0.04 \pm 0.01$ & $0.06 \pm 0.01$ & 7.474 & 0.024 & -0.68 & $-2.677^{* *}$ & $-2.002^{*}$ \\
\hline No. of seeds $\S$ & 15 & $\begin{array}{l}128.2 \pm 16.8 \\
7\end{array}$ & $154.8 \pm 41.08$ & $226 \pm 25.64$ & $169.67 \pm 19.29$ & 4.994 & $0.082^{*}$ & 000 & $-2.402^{*}$ & -1.358 \\
\hline Seed viability (\%) & 30 & $4.1 \pm 0.35$ & $3.5 \pm 0.34$ & $2.6 \pm 0.22$ & $3.4 \pm 0.21$ & 8.734 & $0.013^{*}$ & -1.258 & $-1.944^{*}$ & $-2.784^{* *}$ \\
\hline Pollen viability (\%) & 30 & $7.6 \pm 0.49$ & $7.3 \pm 0.54$ & $5.9 \pm 0.28$ & $6.93 \pm 0.28$ & 6.475 & $0.039^{*}$ & -0.501 & $-1.952^{*}$ & $-2.392^{*}$ \\
\hline
\end{tabular}

Significance based on independent sample Wilcoxon test, rest of the values are based on Kruskal-Wallis test (nonparametric of one-way ANOVA).

$\S$ Number of seeds based at a constant weight of $0.01 \mathrm{gm}$ (number of seeds were counted present at a constant weight of $0.01 \mathrm{gm})$.

Asterisk indicate that the medians for a particular parameter between sites are significantly different from one another at $* p<0.05, * * p<0.01$ and $* * * p<0.001$.

\section{Discussion}

Plant population fitness is influenced by several ecological factors. Populations of M. napaulensis occupied alpine habitats (4117- $4417 \mathrm{~m}$ a.s.l.) experiencing strong ecological heterogeneity. In the majority of cases, plant populations are grown in open rocky habitats in south-west facing slopes. The similarities in most of the edaphic characteristics (such as soil $\mathrm{pH}$, moisture, and litter depth) and substrate types (such as solid rock, non-vascular plant cover, grass cover, and total vascular plant cover) among sites revealed that $M$. napaulensis is habitat specific. Previous studies (Sulaiman and Babu, 1996; Lesica et al., 2006 and Poudeyal, 2010) revealed that certain species of Meconopsis are restricted to extreme edaphic conditions (nutrient-poor, dry, and open rocky substrates) where competition from dominant vegetation is reduced. Debussche and Thompson (2003) reported habitat specialization is the important relative traits for the rare endemic species. The habitat specific species like $M$. napaulensis should have a strong correlation with edaphic endemism and other ecological specificities (Ghimire, 2005; Poudeyal and Ghimire, 2011).

The statistically insignificant difference in the density value of individuals in different stage/state classes (except reproductive size class) among three sites further supports that the population structure and stage class distribution of Meconopsis napaulensis largely depend upon the specific range of ecological amplitude. The regeneration capacity of rare endemic species generally depends upon the availability of suitable micro-habitat (Tilman et al., 1994). The patchy 
nature of $M$. napaulensis could also be linked to the limitation of suitable microhabitat sites in surrounding areas. Thus, the distribution of such rare endemic plants are strongly influenced by the availability of suitable micro-habitat (Tilman et al., 1994).

Regarding the ground cover vegetation, shrubs coverage was found more at the lower altitude site which creates a high competition for the availability of soil nutrients and for sufficient amount of light (Sulaiman and Babu, 1996). It might be the reason of reduction of the density of reproductive individuals at the lower altitude sites. The litter coverage was found significantly higher at lower elevations which showed that habitat at the lower site was more fertile than on the upper site. In this study, the moss coverage was found to be high at the lower elevation site. It retains a high amount of moisture which enhances the vegetative growth of plants (Korner, 2003; Devkota, 2009). Thus, the higher level of vegetative growth of $M$. napaulensis was found to be associated with ecological integration including edaphic factors at the lower altitude. Conversely, the seed production rate was negatively associated with surrounding vegetation. Although the high altitude plant population tries to counteract allocating higher investment towards reproductive growth but due to harsh environmental conditions including poor nutrient substrates, the overall growth of the individual was substantially reduced in comparison to the lower altitude plants.

\section{Distribution:}

Populations of $M$. napaulensis are also influenced by various levels of anthropogenic disturbance like in other parts of Himalaya (Ghimire et al., 2006 and 2008). The over-harvesting of medicinal plants, excessive grazing, and trampling are the major anthropogenic factors which lead to the habitat fragmentation, destruction, and ultimately cause local extinction. In the case of M. napaulensis at Gosainkunda area, grazing seems to be a driving factor for habitat fragmentation along with harvesting for medicinal and religious purposes. The availability of pastoral land towards high altitudes provides the distribution of the grazing resources (Fox et al., 1996; Ghimire et al., 2006). Present findings also indicate that the anthropogenic effect was higher at Gosainkunda site in compare to other sites. As indicators to evaluate disturbances, higher levels of harvesting, grazing, and garbage accumulation in Gosainkunda site proved the higher level of anthropogenic influence on the high altitude population.

Further, most the populations of $M$. napaulensis are along the trekking (Lauribina and Gosainkunda) route and it is one of the important factors that plant populations receive a significant amount of anthropogenic disturbances. Similarly, the Gosainkunda Lake is one of the religiously important lakes among Hindus and Buddhists. Nearly 30,000 pilgrims visit Gosainkunda Lake each year, during the festival 'Janaipurnima' and generate significant human disturbances (personal interviews with locals). During the festival, people who visit usually pluck the flowers and offer them to the Gosainkunda deity. At the mean time collection of capsules for medicinal use was also a prime factor for depletion of the population. Previous study (Poudeyal, 2010) denoted that M. napaulensis roots, leafs, and seeds are used to treat digestive system disorder, chest pain, sore throat, and headache. Premature harvesting of capsules for medicinal purposes was prevalent in Gosainkunda and Lauribina. Thus, an unsustainable harvesting of $M$. napaulensis could be one of the major challenges for the long-term 
population viability. Low to moderate levels of grazing showed a positive relationship with distribution and abundance but higher levels of grazing showed a negative relationship due to the destruction and elimination of the species (Ghimire et al., 2006). The management plan for the pasture land (for grazing) and ecologically iconic species (for conservation) on the same area cannot go independently, so a systematic approach incorporating social management to accommodate the needs of different users at the landscape level is needed (Ghimire et al., 2004 and 2006). Based on the results, M. napaulensis showed identical densities in all stage classes, except reproductive class, among all the three sites. The reproductive (stage) density was significantly high at Lauribina pass. In comparison to the other sites, Lauribina pass received lesser anthropogenic pressure because the site is located away from the human settlements. A previous study suggested that the extent of disturbance in alpine plant population is related to the distance from the settlements (Poudeyal and Ghimire 2011). Thus, Lauribina danda and Gosainkunda sites which are located nearer to the human settlements received a higher amount of disturbances.

Meconopsis napaulensis showed variation in most of the vegetative and reproductive characteristics. The plant height is one of the discriminating characteristics among all the sites. Plants at the lower altitude site (Lauribina danda) were taller in comparison to the high altitude sites. Korner et al. (1983) and Brown et al. (2003) reported that reduction in plant height mostly related to the corresponding decline in temperatures and short growing period in the alpine area. The poor availability of nutrients in the soil, thin soil profile, and further higher level of anthropogenic influence also could be related to the stunted growth of plants in the high altitude site (Gosainkunda). Similarly, the higher allocation on vegetative investment in the lower altitude site supports the production of a higher number of buds, flowers, and capsules. But in contrary to the vegetative growth the number of seeds was significantly high at the high altitude site. Xie et al. (2002) has reported that a large number of seed production is the tendency of rare endemics. Similar is the case for $M$. napaulensis that produces an innumerable number of tiny seeds. Plants at the high altitude site counteracted with that of the lower altitude site by producing a higher number of seeds and a higher allocation towards reproduction in comparison to the vegetative growth. But seed viability tests suggest that the high altitude site produced far less viable seeds. Thus the overall plant performance was found to be always higher in the lower altitude populations. $M$. napaulensis at high altitudes produced light and ill-developed seeds. Seed weight was significantly reduced at higher altitudes if the plants from Gosainkunda $(4417 \mathrm{~m})$ and Lauribina danda $(4117 \mathrm{~m})$ were compared. The maturation and production of intact seeds in alpine plants is directly linked to the favorable environment (Totland, 1997b). The study revealed that alpine plants are more sensitive to temperature for seed feeling and maturation (Wagner and Reichegger, 1997). The frequently changing weather conditions, low temperatures, and short growing seasons hindered the production of healthy and heavier seeds at the higher altitude (Pluess et al., 2005; Wagner and Reichegger, 1997; Totland, 1997b; Totland and Birks, 1996; Corbet, 1990; Galen, 1985). The production of intact seeds per plant was also related to the extent of disturbance. Escarre et al. (1999) reported that floral damage by herbivores limits the seed production. Similarly, suitable pollinator limitation, pollen limitation in a fragmented habitat 
like M. napaulensis are also major challenges to develop well-firmed seeds in alpine habitats (Morely, 1982; Menges et al., 1986; Karran, 1987; Lavergne, 2005; Albert et al., 2005).

\section{Conclusion}

Meconopsis napaulensis prefers an open rocky substrate, nutrient-poor, grassy slopes in south-west facing slopes. Habitat characteristics are directly linked to the vegetative and reproductive attributes. Lower altitudes provide fertile and nutrient-rich habitat for vegetative growth and reproductive outputs.

Vegetative and reproductive traits of Meconopsis napaulensis showed variation along the elevation gradient. Lower altitude plants showed proliferation towards the vegetative outputs in comparison to higher altitude which could be linked to the favorable environment such as higher level of soil nutrients, moisture, and higher temperature.

In contrary to the vegetative growth, high altitude plants tended to show a higher number of seeds per capsule. Thus in this regard, a tradeoff among the plant traits was observed in which lower altitude plants invest higher allocation on vegetative growth and lesser investment on reproductive growth and development. Contrarily, high altitude plants showed a higher investment on reproductive output in comparison to the vegetative investment.

Plants in four stage/size classes did not showed marked differences in density, but numerically the number of large rosettes is slightly higher than that of all other stages. The population structure was identical in all sites studied. In regards to density of the plants, reproductive plant density was markedly differed among all the sites and stages. The reproductive density was far higher in Lauribina pass which could be linked to the safe habitat in comparison to the other two sites. The latter two sites were nearer to the human settlements and received a higher level of disturbances.

\section{Acknowledgements}

We are thankful to Department of National Parks and Wildlife Conservation (DNPWC) and Langtang National Park (LNP) for granting permission to carry out this work inside the National Park Area under the Biodiversity Associates for Research, Development and Action, Nepal (BARDAN). Our sincere thanks goes to the local people of Deurali, Chandanbari, Cholangpati, Lauribina, and Gosainkunda for their help and support, and for sharing their knowledge about the studied species.

\section{References}

Albert MJ, Escudero A, Iriondo JM. Assessing ant seed predation in threatened plants: A case study. Acta Oecologia, 2005;28 : 213-220.

Baskin CC, Baskin JM. Seeds: Ecology, Biogeography and Evolution of Dormancy and Germination. 1998. Academic Press, San Diego, USA. 
Bharali S, Paul A, Khan ML, Singha LB. Impact of altitude on population structure and regeneration status of two Rhododendron species in a temperate broad-leaved forest of Arunachal Pradesh, India. International Journal of Ecosystem. 2012; 2: 19-27.

Blionis GJ, Vokou D. Reproductive attributes of Campanula populations from Mt Olympos, Greece. Plant Ecology. 2005; 178: 77-88.

Brune EM, Kress WJ. Habitat fragmentation and demographic structure of an Amazonian Understory herb (Heliconia acuminataa). Conservation Biology. 2002; 16 : 1256-1266.

Cavaliere C. The effect of climate change on medicinal and aromatic plants. Herbal Gram. 2009; 81 : 44-57.

Colling G, Matthies D. Effects of habit deterioration on population dynamics and extinction risk of an endangered, long-lived perennial herb (Scorzonera humilis). Journal of Ecology. 2006; 94 : 959-972.

Daiz S, Cabido M, Zak M, Martinez, Eduardo Aranibar J. Plant functional traits, ecosystem structure and land-use history along a climatic gradient in central-western Argentina. Journal of Vegetation Science. 1999; $10: 651-660$.

Dar AR, Dar GH, Reshi Z. Conservation of Artimisia amygdalina - a critically endangered endemic plant species of Kashmir Himalaya. Endangered species Update. 2006; 23 : 34-39.

Dar AR, Reshi Z, Dar GH. Germination studies on three critically endangered endemic angiosperm species of the Kashmir Himalaya, India. Plant Ecology, 2009; $200: 105-115$.

Egan PA, Shrestha S. Meconopsis .In: Watson et al.,(ed), Flora of Nepal Volume 3. Royal Botanical Garden Edinburgh. 2011.

Ghimire SK. The endemic flora in Dolpo, north-west Nepal: distribution patterns, life forms, habitat specificity and conservation status. Botanica Orientalis. 2005; 5: $30-39$.

Ghimire SK, McKey D, Aumeeruddy-Thomas Y. Himalayan medicinal plant diversity in an ecologically complex high altitude anthropogenic landscape, Dolpo, Nepal. Environmental Conservation. 2006; 33:128-140.

Ghimire SK, Thapa-Magar S, Shrestha MR, Devkota B, Gubhaju MR. Identification of Important Plant Areas (IPAs) in Shivapuri-Langtang Linkage Area of Sacred Himalayan Landscape, Nepal. Unpublished Report. WWF Nepal Program, Kathmandu. 2008.

Grey-Wilson C. The true identity of Meconopsis napaulensis DC. Curtis's Botanical Magazine. 2006; $23: 176-209$.

Harper JL. Population Biology of Plants. Academic Press, New York. 252 R. Brys et al. / Acta Oecologica. 1977; $24: 47-253$.

Jenny-Lips H. Vegetation der Schweizer Alpen. Gutenberg, Zu“rich. 1948.

Karran JD. A comparison of levels of genetic polymor- phism and self- compatibility in geographically restricted and widespread plant congeners. Evolution Ecology.1987; $1: 47-58$.

Kim E, Donohue K. Demographic, developmental and life- history variation across altitude in Erysimum capitatum. Journal of Ecology. 2011; 99 : 1237-1249.

Korner C. 2003. Alpine plant life. Springer, Berlin Laine K, E. Malila, M. Siuruainen, 1995. How is annual climatic variation reflected in the production of germinable seeds of arctic and alpine plants in the northern Scandes? European Commission, Bru"ssel, pp 89-95.

Landolt E. Gebirgs- und Tieflandsippen von Blu"tenpflanzen in Bereich der Schweizer Alpen. Bot Jahrb Syst Pflanzengesch Pflanzengeogr. 1967; 86 : 463-480.

Lavergne S. Limitation on reproduction success in endemic Aquilegia viscosa (Ranunculaceae) relative to its wide spread congener Aquilegia vulgaris: the interplay of herbivory and pollination. Oecologia,. 2005; $142: 212-220$.

Leishman M, Writh IJ, Moles AT, Westoby M. The evolutionary ecology of seed size. In: Fenner M (ed) Seeds. CABI, New York, 2000; pp 31-57

LennartssonT. Extinction thresholds and disrupted plant-pollinator interactions in fragmented plant populations. Ecology. 2002; $83: 3060-3072$.

Lesica P, Yurkewycz R, Crone EE. Rare plants are common where you find them. American journal of Botany. 2006;93:454-459.

Lin CH, Chen BS, Yu CW, Chang SW. A water based Triphenyl Tetrazolium Chloride method for the elevation of green plant tissue viability. Phytochemical analysis. 2001;12: 211-213.

Menges ES, Waller DM, Gawler SC. Seed ser and seed predation in Pedicularis furbishiae, a rare endemic of the St. John River, Maine. American Journal of Botany 1986; 73:1167-1177.

Moles AT, Westoby M. Seedling survival and seed size: a synthesis of the literature. Journal of Ecology. 2004; $92: 372-383$.

Morley T. Flowering frequency and vegetative reproduction in Erythronium albidum and E. propullans, and related observations. Bull. Torrey Bot. Club.1982; 109:169-76. 
Pluess AR, Schutz W, Sto cklin J. Seed weight increases with altitude in the Swiss Alps between related species but not among populations of individual species. Oecologia. 2005; $144: 55-61$.

Salick J, Zhendong F, Byg A. Eastern Himalayan alpine plant ecology, Tibetan ethnobotany, and climate change. Global Environmental Change. 2009. 19:147-155.

Sano M, Furuta F, Kobayashi O, Sweda T. Temperature variations since the mid-18th century for western Nepal, as reconstructed from tree- ring width and density of Abies spectabilis. Dendrochronologia.2005; $23: 83-92$.

Sharma CM, Suyal S, Gairola S, Ghildiyal SK. Species richness and diversity along an altitudinal gradient in moist temperature forest of Garhwal Himalaya. Journal of American Science. 2009; $5: 119-128$.

Sulaiman IM. Seed germination studies in three species of threatened, ornamental , Himalayan poppy, Meconopsis Vig.(Papaveraceae). Seed Science and Technology. 1993; 21 : 593-603.

Sulaiman IM, Babu CR. Ecological studies on five species of endangered Himalayan yellow poppy, Meconopsis (Papaveraceae). Biological Journal of Linnean Society. 1996; 121 : 169-176.

Tilman D, May RM, Lehman CL, Nowak MA,. Habitat destruction and the extinction debt. Nature Areas Journal.1994; $371: 65-66$.

Totland $\varnothing$, Birks HJB. Factors influencing inter-population variation in Ranunculus acris seed production in an alpine area of southwestern Norway. Ecography.1996;19: 269-278.

Totland $\varnothing$. Effects of flowering time and temperature on growth and reproduction in Leontodon autumnalis var. taraxaci, a late-flowering alpine plant. Arctic, Antarctic, and Alpine Research 1997b; $29: 285-290$.

Wana D, Beierkuhnlein C. The relative abundance of plant functional types along environment gradients in the southwest Ethiopian highlands. Journal of Tropical Ecology. 2009; 54-83.

Wagner J, Reichegger B. Phenology and seed development of the alpine sedges Carex curvula and Carex firma in response to contrasting topo climates. Arctic, Antarctic, and Alpine Research. 1997; $29: 291-299$

Wang T, Liang YH, Ren B, Yu D, Ni J, Ma KP. Age structure of Picea schrenkiana forest along an altitudinal gradient in the central Tianshan mountains, north western china. Forest Ecology and Management. 2004; $196: 267-274$.

Westoby M, Wright J. Land -plant ecology on the basis of functional traits. Trends in Ecology and Evolution. 2006;21:261-268.

Wright SJ, Bunker D, Dalling J, Davies S, Diaz S, Engelbrecht B, Harm K, Kitajima K, Kraft N, Marjs C, Reich P, Valencia R, Wright I, Zanne A. Towards a functional traits based research program within the Center for Tropical Forest Science. 2006.

Xie Y, Xu J, Fang Z. Conservation Biology of Himalayan Poppies (Meconopsis spp.) in Northwest Yunnan, China: in situ and ex situ cultivation. In: Himalayan Medicinal and Aromatic Plants, Balancing Use and Conservation (Y.Thomas, M. Karki, K.Gurung and D. Parajuli, eds), 2002; 328-349. Ministry of Forest and Soil Conservation, Government of Nepal, Kathmandu,Nepal. 